\title{
Prevalence and sero-epidemiology of bluetongue with special reference to eastern and north-eastern states of India
}

Siddhartha Narayan Joardar ${ }^{*}$ (D)

\begin{abstract}
Background: Bluetongue (BT), an infectious, non-contagious arthropod borne viral disease of domestic and wild ruminants is caused by bluetongue virus (BTV), a type species of Orbivirus genus and Reoviridae family. Albeit bluetongue in India is endemic to southern and western parts, eastern and north-eastern parts of the country didn't experience any outbreak or reported active disease.

Main body of abstract: International, national and regional disease statuses including some un-published data were narrated to give a clear picture. Until 1940s, BT was mainly restricted to African countries, however started spearheading to Asian and European countries subsequently. Extensive epidemiological surveys were conducted in central parts of America and Caribbean countries during late 80's. Massive ingression of BT was observed in northern Europe 2006 onward. In India, although first reported in 1964, BT became endemic in southern states during 1980s and became alarming in late 1990s. A thorough sero-epidemiological study was conducted in different agro-climatic zones of eastern and north-eastern states of India during 2001 to 2017. Sero-epidemiological information of different states had been tabulated. This was the first comprehensive document of BT sero-epidemiology of eastern and northeastern parts of India. Although BT was not reported officially, sero-epidemiology showed BTV was in circulation in animals and vectors of eastern and north-eastern states of India. Published as also un-published data clearly showed animals and vectors harbor BTV in this part of the country.
\end{abstract}

Short conclusion: All the epidemiological components of BT are present in eastern and north-eastern parts of India that warrants presence of the disease in these parts also. Hence, further surveillance and preparedness are recommended to avoid future BT outbreak, if any.

Keywords: Bluetongue, Culicoides, Ruminants, Sero-epidemiology, Vector, Virus

\section{Background}

Bluetongue (BT) is an infectious, non-contagious arthropod borne viral disease of domestic and wild ruminants. The disease has been recognized not only in sheep, goat and cattle but also in other domestic animals like water buffaloes, camels and wild ruminants (white tailed deer, elk, blesbuck and elephants) (Ruiz-Fons et al., 2008). In

\footnotetext{
*Correspondence: joardar69@gmail.com

Department of Veterinary Microbiology, Faculty of Veterinary and Animal

Sciences, West Bengal University of Animal and Fishery Sciences, 37

Kshudiram Bose Sarani, P.O.-Belgachia, Kolkata 700037, India
}

sheep the disease is acute and mortality may be high, whereas in goats and cattle the disease is milder. In contrast to sheep, infected bovines experience prolonged viraemia and act as reservoir hosts for BT virus (MacLachlan \& Dubovi, 2011). For many decades the disease was believed to be confined to the South African continent. The first outbreak occurred in the island of Cyprus. Although BT was first reported in 1964 in India (Maharashtra state) based on clinical signs and detection of anti-bluetongue antibodies (Sapre, 1964), isolation of virus could be made only during 1972. In India, the disease is reported to be an important emerging disease 
affecting large number of sheep. The disease is now included within the category of multiple species disease as per the World Animal Health Information SystemOIE, which prevents the export of animals, their products and germplasm from bluetongue endemic to bluetongue free country, thus disrupting international trade.

The bluetongue virus (BTV), a type species of Orbivirus genus and Reoviridae family, is the causative agent of bluetongue disease (Attoui et al., 2009). BTV is transmitted by Culicoides midges. Culicoides midges have been shown to transmit the virus biologically between sheep, from cattle to sheep, between cattle, between domestic ruminants to wild and from wild to domestic ruminants. After infection, bluetongue virus replicates in Culicoides and the fly remains infected for life. BT is usually enzootic in areas where Culicoides vectors are present for most of the times of the year, thus maintaining a continuous cycle of the virus. The species of Culicoides are most active in the temperature range of $18-29^{\circ} \mathrm{C}$ and become almost inactive below $10^{\circ} \mathrm{C}$ or above $30^{\circ} \mathrm{C}$. Though there are more than 1400 species of Culicoides worldwide, less than 20 are known to transmit BTV (Chand et al., 2014). These include C. imicola, C. veripennis, C. fulvus, C. actoni, C. wadi, C. nubeculosis etc. Culicoides vectors usually strike sheep flocks during late evening. Only female midges take blood meal from vertebrate hosts prior to egg lay. The disease is prevalent in late summer and early autumn that provide congenial environment for multiplication of vectors.

The disease in sheep is characterized by high fever, depression, catarrhal inflammation and oedema causing swelling of lips, nose, face, sub-mandibulum, eyelids and ears, congestion of buccal and nasal mucous membrane, conjunctivitis, hyperaemia of skin (groin, axilla and perineum) and coronary bands, lameness due to coronitis or degeneration of skeletal muscle. Congested tongue becomes swollen and cyanotic. There is serous nasal discharge that becomes mucopurulent later (MacLachlan \& Dubovi, 2011).

Bluetongue in India is endemic to Tamil Nadu, Andhra Pradesh and Karnataka. Sporadic reports are available from Maharashtra, Gujarat, Rajasthan, Haryana, Himachal Pradesh and Jammu \& Kashmir. Till date, 29 BTV serotypes have been identified worldwide (Yang et al., 2021). A total of 23 serotypes (except 22, 25-29) have been reported from India by serological assays and/ or virus isolation mostly in Maharashtra, Uttar Pradesh, Tamil Nadu, Andhra Pradesh with scanty evidences from Haryana, Himachal Pradesh, Karnataka, Jammu and Kashmir, West Bengal, Rajasthan, Gujarat, Uttarakhand, Madhya Pradesh (Chand et al., 2014; Hemadri et al., 2017). So far, 15 serotypes (BTV-1 through 6, 9, $10,12,16$ through $18,21,23$ and 24) were identified by virus isolation, while 22 serotypes (BTV-1 through 20, 23 and 24) were reported by serological testing (Saminathan et al., 2020). The occurrences of bluetongue have variations in different parts of India depending on time of rainfall. Maximum numbers of outbreaks were recorded during north-east monsoon period (October to December) followed by the south west monsoon period (June to September) in Andhra Pradesh (Anon., 2014). Similarly in Tamil Nadu the outbreaks were more frequent during the north-east monsoon period. In Rajasthan, the outbreaks were mostly recorded during months of September and November.

Eastern and north-eastern parts of the country didn't experience any outbreak or reported active disease. But that doesn't warrant declaring the states as bluetongue free; as always there exists a complex interaction between BTV, Culicoides midges (vector), susceptible hosts (sheep, goats, cattle, buffalo and wild animals) and environmental factors that finally give rise to active disease. It is quite expedient to explore this interaction in a holistic manner to reveal the prevalence of sub-clinical bluetongue and circulating BTV in the states, if any. Hence a thorough sero-epidemiological study was conducted in the eastern and north-eastern states of India primarily followed by isolation and characterization of bluetongue virus (BTV) from susceptible hosts and vectors. The study was conducted July, 2001 through March, 2017.

\section{Main text \\ Prevalence of bluetongue: historical perspective International scenario}

In South Africa, bluetongue shattered the livestock industry for long, may be from the very beginning of sheep farming. Henning (1949) noted that the Report of the Cattle and Sheep Diseases Commission for 1876 stated: "For many years, if not from the time of the introduction of the Merino sheep into the Colony, there has been prevalent among the flocks; a disease known as "fever". This disease is most prevalent during the summer months, and is very much worse in wet seasons." Hutcheon reported bluetongue in 1881, referring to it as "fever or epizootic catarrh" in sheep. Spreull (1905) was the first to study the disease in detail. In 1933, bluetongue was recognized for the first time as a disease of cattle. In these animals it apparently gave rise to a stomatitic infection similar to foot-and-mouth disease.

In 1943, an outbreak occurred in Cyprus and later in Turkey (Gambles, 1949). Bluetongue caused a major epizootic during 1956-57 in Portugal and Spain in which $1,79,000$ sheep died resulting in $75 \%$ mortality rate (Manso-Ribiero \& Noronha, 1957). In Israel, the disease was reported in 1951 (Komorov \& Goldsmit, 1951). 
BT disease was reported in Japan by many workers (Omori, 1961; Inaba et al., 1966; Ishitani, 1967).

Australia was considered to be free from BT disease till 1977. However, bluetongue virus (BTV) was isolated from insect and healthy cattle in 1978 (St. George et al., 1980).

Bluetongue was first described in South Africa, where it has probably been endemic in wild ruminants since antiquity. It is currently recognized that BT is endemic throughout most of South Africa and 22 of the 26 known serotypes have been detected in the region. Multiple serotypes circulate each vector season with the occurrence of different serotypes depending largely on herdimmunity. Indigenous sheep breeds, cattle and wild ruminants are frequently infected but rarely demonstrate clinical signs, whereas improved European sheep breeds are most susceptible (Coetzee et al., 2012).

The central focus of BTV research was roaming around Africa. However, it became increasingly clear that the being unrecognized BTV was circulating in some countries across a broad endemic range encompassing tropical, subtropical and even some temperate regions, reaching to almost $50^{\circ} \mathrm{N}$ in North America (Dulac et al., 1989).

Between 1987 and 1992, a regional prospective study was carried out on the epidemiology of bluetongue virus (BTV) serotypes covering 11 countries in Central America and the Caribbean. In this study, over 300 BTV isolations were done from cattle and sheep. Extensive network of sentinel herds in the Central America detected BTV-1 as the predominant serotype besides BTV-3 and BTV6. In Puerto Rico and the Dominican Republic, BTV-4 became the predominant serotype, without detection of BTV-8 and BTV-17, which were common in one of the studies (Mo et al., 1994).

In 1998, BTV-9 was detected on four Greek islands (Rhodes, Leros, Kos and Samos). It was considered as the most extensive, prolonged and costly period of BTV incursions into Europe in recorded history (Mellor \& Wittmann, 2002; Purse et al., 2005).

The involvement of bluetongue virus (BTV-2 and BTV9) was confirmed serologically and virologically in the outbreaks and mortalities (about 11\%) of three sheep holdings communities of Itally at San Gregorio Magno, Laviano and Carpino between July and September 2002 (Savini et al., 2005).

BTV was detected in northern Europe for the first time in 2006. The outbreak of bluetongue, caused by a BTV-8 strain, thought to be of sub-Saharan origin (Maan et al., 2008).

BT was noticed in a sheep flock at the border of Belgium and the Netherlands in 2006 and very soon spread across Belgium, Netherlands, Germany, Luxemburg and
France (Toussaint et al., 2007 and Meroc et al., 2008). The outbreak also reported clinical disease in sheep and cattle (Thiry et al., 2006). The virus responsible for this epidemic was isolated and identified as BTV-8, a serotype not previously encountered in Europe (Toussaint et al., 2007). Besides livestock, red deer (Cervus elaphus) was also found to be susceptible for BTV-8 as shown by seroconversion in 2006 outbreak (Linden et al., 2008).

Re-emerging bluetongue virus serotype 8 (BTV-8) in Germany was detected first in May 2007 in a sentinel cow and in February 2008 in an export heifer (Hoffmann et al., 2008a).

A few new field strains have been isolated from the Caribbean region during 2012 (Legisa et al., 2013). These strains were obtained in French Martinique Island (BTV $2,10,11,13,17,18,22$, and 24) and Guadeloupe Island (BTV5 and 17).

Lager et al. (2004) isolated BTV4 from sentinel cattle which sero-converted in 1999-2001 from Argentina's northeast region. Clavijo and co-workers isolated BTV12 from an outbreak reported in Parana state in Brazil (Clavijo et al., 2012).

During January-April 2014 samples from goats were analyzed and the virus showed genome sequence was similar to that of the BTV-25 segment 2. The virus showed highest identity with the BTV-25 and BTV-26 serotypes circulating in Switzerland and Kuwait, respectively (Maan et al., 2011; Hofmann et al., 2008b).

The complete segment 2 sequence of the new virus from Corsica (termed BTV-n) shared 73\% nucleotide and $75 \%$ amino acid identify with BTV-25 sequences and $65 \%$ nucleotide and $60 \%$ amino acid identity with BTV-26 sequences (Zientara et al., 2014).

The clinical, pathological and epidemiological aspects of 17 outbreaks of bluetongue (BT) disease in sheep occurring between December 2014 and July 2015 in the central region of Rio Grande do Sul state (RS), southern Brazil was reported. The virus involved in the outbreaks was subsequently isolated and shown to belong to serotype 17, for the first time reported in Brazil (Bianchi et al., 2017).

\section{Indian scenario}

The first outbreak of BT in sheep and goats in the country was recorded in 1964 in Maharashtra by Sapre (Sapre, 1964). In 1973, an outbreak of BT was recorded in Russian Merino sheep, on Kothipura Farm in Himachal Pradesh (Uppal \& Vasudevan, 1980). Later, a further outbreak of BT was reported in 1975 in exotic 'Corriedale' sheep in the Central Sheep Breeding Farm (CSBF), Hisar, Haryana.

An outbreak of BT in sheep in Bidar, Gulbarga and nine other districts of Karnataka was reported where 
morbidity was 50\% (Vasudevan, 1982; Srinivas et al., 1982).

BT has been reported in several states of India, including northern (Haryana, Himachal Pradesh, Jammu and Kashmir, Punjab, Rajasthan and Uttar Pradesh), central (Madhya Pradesh), western (Gujarat and Maharashtra) and southern areas (Andhra Pradesh, Karnataka, and Tamil Nadu). However, there are no reports of BT in the northeastern states of India (Prasad, 2000; Prasad \& Srivastava, 1995; Sreenivasulu et al., 1996; Srivastava et al., 1995).

An outbreak of BT occurred in eastern Maharashtra adjoining to the Telangana region of Andhra Pradesh (southern India), which later spread to western Marathawada, affecting sheep in all districts of the region with up to $80 \%$ morbidity in some village flocks (Singh et al., 1982).

Harbola et al. (1982) recorded an outbreak of BT in Maharashtra state and suggested that crosses of the native Chokla breed with Merinos were more susceptible than the native breed itself, although Deccani sheep (another native breed) also showed clinical signs during the outbreak. Of 8,980 exotic, crossbred and native sheep, 868 were affected clinically, 100 of which died, giving an overall case fatality rate of $11.5 \%$.

In 1983, an outbreak of BT was recorded in Rajasthan, in which Rambouillet and Merino breeds were found to be more susceptible than native breeds. The morbidity rate in Merino and Rambouillet was $33 \%$ and $24 \%$, respectively. Sharma et al., (1985) conducted a systematic epidemiological study in the Central Sheep and Wool Research Institute (CSWRI), Rajasthan and reported a fatality rate of $15 \%$.

An epidemiological study carried out in Central Sheep Breeding Farm (CSBF), Hisar, revealed mortality and case fatality rates of $13.3 \%$ and $31 \%$, respectively in 1985 , which increased to $16.7 \%$ and $43 \%$, respectively in 1986. In 1987 and 1988 the mortality rate fell back to $7 \%$ (Mahajan et al., 1991).

A widespread outbreak of BT in the native sheep of Tamil Nadu occurred during November and midDecember 1989 (Mehrotra et al., 1991). A concurrent outbreak of BT and morbillivirus (PPRV) in sheep of Maharastra was reported by Mehrotra et al. (1996). The morbidity and mortality was observed among indigenous and exotic breeds of sheep and in all outbreaks distinct clinical disease was distinct.

Kulkarni et al. (1992) also reported severe outbreaks of BT in native sheep in rural areas of Maharashtra, with overall morbidity, mortality and case fatality rates of $32 \%$, $8 \%$ and $25 \%$, respectively.

All of the southern Indian breeds of sheep were found to be susceptible to disease and developed clinical BT, although Saravanabava (1992) reported variations in susceptibility between breeds.

Bluetongue outbreak was studied in detail in six western districts of Tamil Nadu namely, Namakkal, Salem, Erode, Coimbatore, Karur and Dindigul during 20032006. The classical signs of cyanosis of the tongue and reddening of the coronary band in native sheep, Macheri breed, were observed (Anon, 2006).

During 1995-2007, a total number of 4124 outbreaks were observed in different parts of Andhra Pradesh. During the outbreak, 103658 numbers of animals died and the case fatality rate was 20.86 (Anon, 2008a).

During the year 2007-2008, there were 142 outbreaks of the disease reported in seven districts covering the Eastern and Central parts of Karnataka. Totally 2685 animals were affected resulting in 410 deaths among the small ruminants (Anon, 2008b).

During the year 2013-2014, 114 outbreaks were reported from Karnataka. Out of those outbreaks 452 blood samples were collected and tested. Total 77 samples were positive for bluetongue virus by RT-PCR (Anon, 2014).

\section{Sero-epidemiology of bluetongue International status}

Seroprevalence study on BTV during 1982 through 1984 employing 2550 cattle serum samples randomly selected from 274 herds revealed that $39 \%$ of the serum samples were positive in Louisiana State as assessed by Enzyme Linked Immunosorbent Assay (ELISA) (Hugh-Jones et al., 1989).

In an epidemiological survey on sero-incidence of BTV in Jiangsu province of China, 68 (1.5\%) out of 3853 cattle sera and $63(2.2 \%)$ of 2426 sheep and goat sera were detected as positive, respectively as assessed by ELISA (Chang et al., 1995).

To estimate sero-prevalence of bluetongue virus (BTV) and the geographic distribution of sero-positive cattle herds in Illinois and western Indiana, serum samples $(10,585)$ obtained from cattle was tested using competitive ELISA. Overall, BTV antibodies were detected in $156(1.5 \%)$ samples. In the southernmost zone, annual seroprevalence ranged from $8.65 \%$ to $11.00 \%$. Adult cattle were 2.35 times as likely as juvenile cattle to be seropositive (Boyer et al., 2007).

A total of 204 goat samples (10.2\%) from 38 locations with goats $(46.9 \%)$ were seropositive. A total of 1,627 sheep samples (38.3\%) from 149 locations with sheep (69.6\%) were seropositive in Netherlands during 2006 (Elbers et al., 2008).

The presence of antibodies to BTV in wild ruminants was studied in Belgium and Germany. In 2006, BTV 
seroprevalence was $0.58 \%$ in Belgian cervids (Linden et al., 2008). The survey in Germany showed BTV seroprevalence rates of $0.09 \%$ in red deer, $5.7 \%$ in roe deer, and $4.9 \%$ in mouflon (Francisco et al., 2008).

Out of 1898 serum samples (439 roe deer, 480 red deer, 473 chamois, 506 ibex) screened for BTV antibodies by ELISA, 118 showed an optical density percentage (ODP, inversely proportional to the optical density $\mathrm{OD}$ ) value greater than $30 \%$, which was the cut-off determined for this study. Ten of the 118 samples with an ODP $>30 \%$ was observed in Switzerland. Overall, estimated seroprevalence was $0.5 \%$ (95\% confidence interval [CI] 0.3-1\%) (Casaubon et al., 2013).

A total of 756 serum samples were collected from west and northwest provinces of Iran during 2007-2008. Sera were tested with competitive enzyme-linked immunosorbent assay (c-ELISA). The seroprevalence rate in sheep was 40.87\% (Khezri \& Azimi, 2013a).

A total of 996 sheep sera were collected from 8 provinces in Iran and tested for Bluetongue virus specific antibody using c-ELISA. The results showed that the seroprevalence of BT in sheep was 34.93\%, with the highest and lowest prevalence seen in West-Azerbaijan (64.86\%) and Qom (12.1\%) areas, respectively (Khezri \& Azimi, 2013b).

A total number of 1293 animal serum samples (sheep1028 and goats-265) were collected during the vector breeding time from September to November, 2010 in Egypt. A substantial number of sheep (17.5\%) and goat (14.7\%) were found positive when tested by Agar Gel Immuno-precipitation Test (AGPT) (Mahmoud \& Khafagi, 2014).

A sero-epidemiological study was conducted to determine the seroprevalence and associated risk factors of bluetongue in small ruminants of South Western Ethiopia. A total of.

422 serum samples were screened for the presence of bluetongue virus (BTV) specific antibodies using c-ELISA and $30.6 \%$ of the sheep and goat serum samples were found positive (Abera et al., 2018).

\section{Indian status}

While assessing serum samples for anti-BT antibodies from seven states (Andhra Pradesh, Karnataka, Gujarat, Punjab, Orissa, Himachal Pradesh and West Bengal) during early 80 's, $18 \%$ of cattle sera were found positive for BTV antibodies (Mehrotra \& Shukla, 1984).

Oberoi et al. (1988) demonstrated the presence of BTV specific antibodies in $70 \%$ of cattle sera in Punjab state. In Haryana, $4.2 \%$ cattle sera were found positive for BT antibodies (Jain et al., 1992).

One c-ELISA directed against VP7 of BTV was used with 133 sheep, 134 goats, 147 cattle and 43 buffalo serum samples for BTV precipitating antibody. Twenty five sheep sera (18.7\%) from Haryana, Himachal Pradesh and Punjab were found positive. Out of 134 goat serum samples screened from Haryana, HP and Rajasthan, 102 (76\%) were found positive for BTV antibody while of 137 cattle serum samples, 83 (60.5\%) were found positive for BTV antibody. Of the 43 buffalo serum samples collected from Punjab and Haryana, 26 (16.5\%) were found positive for BTV antibody (Naresh \& Prasad, 1995).

When c-ELISA was employed to detect incidence of BTV with 26 cattle sera, the incidence varied from 17 to 89\% (Singer et al., 1997).

While conducting serological survey on BTV in catthe at selected sites in Andhra Pradesh, Karnataka and Tamilnadu by c-ELISA using polyclonal antibody it was recorded seroprevalence rate as $65.91 \%, 79.51 \%$ and 80.95\% in Andhra Pradesh, Karnataka and Tamilnadu, respectively (Dayakar et al., 2001).

Kakker et al. (2002) carried out extensive serological survey in northern India (Haryana, Himachal Pradesh, Punjab, Jammu \& Kashmir and Rajasthan) and detected BTV specific antibodies in $23.4 \%$ of the cattle tested.

A comparative study was done to assess the performance of the standard AGID test and the c-ELISA for detection of antibody against BTV in clinically healthy and diseased camels in Gujarat. Out of 176 sera tested, $22(12.55 \%)$ and 34 (19.3\%) were positive for group specific bluetongue antibodies by AGID and cELISA, respectively. Maximum seropositivities of $18 \%$ by AGID and $25.8 \%$ by c-ELISA were recorded in Kutchhi breed, and of $6.9 \%$ and $12.65 \%$, respectively, in Marwari breed (Chandel et al., 2003).

A total of 1,010 sera collected from the 14 districts of Kerala were screened for the presence of group-specific BTV antibodies by dot enzyme-linked immunosorbent assay (dot ELISA). The overall BTV antibody prevalence was $5.1 \pm 1.9 \%$ (Ravishankar et al., 2005).

In Maharashtra State, a total of 453 sera comprising 218 sheep, 148 goats, 52 cattle and 35 buffaloes were collected and screened by c-ELISA for qualitative analysis of the BT antibodies. A high percentage of animals showed BT antibodies consisting of $40.36 \%$ sheep, $64.86 \%$ goats, $30.76 \%$ cattle and $37.14 \%$ buffaloes. The overall percentage of BT positive animals was $47.01 \%$ (Waghmare \& Deshmukh, 2006).

While conducting serological survey on BTV in goat in Nagpur district of Vidarbha region by c-ELISA it was found, out of 250, 129 (51.60\%) serum samples were positive. The highest prevalence was observed in Bhivapur tehsil (68.29\%) followed by Kalmeshwar (64.51\%) and in Nagpur Rural (57.57\%) (Potey et al., 2006).

In West Bengal one serological assessment was conducted for BT infection using different species of animals 
(322 sheep, 104 goats and 74 cattle). Out of 500 serum samples screened by c-ELISA, 111 (34.47\%) sheep, 25 (24.03\%) goats and $12(16.21 \%)$ cattle were found to be positive (Chakrabarti et al., 2007).

Serological surveillance of bluetongue virus (BTV) group-specific antibody in goats of the coastal saline (Sunder ban) area of West Bengal was conducted. Fieldcollected goat sera $(n=1202)$ were tested and a serological prevalence rate of $47 \%$ was observed in the study area (De et al., 2008).

When c-ELISA was performed to assess anti-bluetongue antibodies in sheep, goat and cattle of different agro-climatic zones (Old alluvial, New alluvial, Red laterite and Coastal saline) of West Bengal, it was found that $66.97 \%$ of goat, $59.68 \%$ of sheep and $33.33 \%$ of cattle were positive. The overall sero-positivity was $60.44 \%$ (Biswas et al., 2009).

The sero-epidemiological investigation on bluetongue was carried out from November 2007 to March 2008 in Jammu province. A total of 200 sera (61 from sheep and 139 from goat) were screened using indirect-ELISA (i-ELISA) for detection of bluetongue virus group-specific antibody. An overall sero-prevalence of $29.5 \%$ was found, which was significantly higher $(P<0.05)$ in goats $(37.4 \%)$ as compared to sheep (11.5\%). The prevalence in goats was highest in district Kathua (59.1\%) followed by Udhampur (45.0\%), Samba (32.4\%) and Jammu (30.2\%). In sheep, it was highest in Samba (25.0\%) followed by Kathua (22.2\%) and Udhampur (6.8\%) districts (Singh et al., 2009).

When 302 numbers of animals comprising 137 sheep, 115 goat and 50 cattle, covering five agro-climatic zones (Old alluvial, New alluvial, Red laterite, Coastal saline and Terai) and seven districts (Jalpaiguri, Dakshin Dinajpur, Malda, Nadia, Burdwan and South 24 Parganas) of West Bengal were screened by i-ELISA, $66.95 \%$ goat, $57.66 \%$ sheep and $52 \%$ cattle were found to have antibluetongue antibodies (Panda et al., 2011).

During 2009 when sheep serum samples of West Bengal were assessed by $\mathrm{i}$-ELISA, it was found that $47.72 \%$ serum samples possessed anti-BT antibody. In case of goat and cattle the percentages were 55.66 and 56.82, respectively (Halder, 2011).

When 160 sheep sera of West Bengal were collected and screened by both c-ELISA and dipstick ELISA, 54 samples (33.75\%) and 51 samples (31.87\%) were found positive, respectively (Mandal et al., 2012).

A sero-surveillance conducted in the Pithoragarh hills of Uttarakhand in India during the autumn of 2011. Of the 51 collected samples, $18(35 \%)$ were positive to an indirect ELISA and $33(64 \%)$ resulted positive to a BTV ELISA antigen (Mondal et al., 2013). The goat serum samples were found to contain high titer of neutralizing antibodies against BTV-23, nonetheless the virus could not be isolated.

Out of 313 animal serum samples screened (sheep68 , goat-195and cattle-50), $58.82 \%$ of sheep, $31.79 \%$ of goat and $70.00 \%$ of cattle samples were found positive in Assam. The overall seropositivity against anti-bluetongue antibodies ranged from $31-50 \%$ in different agro-climatic zones of Assam (Joardar et al., 2013).

A total of 91 serum and 26 whole blood samples were obtained from sheep and goat from Uttar Pradesh to conduct a study between September and November, 2012. Of the 91 small samples examined, 26 (28.6\%) were found to harbor BTV antibody by c-ELISA. Similarly, species level prevalence of BTV antibody was 8 (13.8\%) and 18 (54.5\%) in sheep and goats, respectively (Bitew et al., 2013).

When total 364 animal sera were screened by i-ELISA, 32 of sheep (26.66\%), 35 of goat (31.25\%) and 69 (52.27\%) of cattle samples were found positive in Orissa (Joardar et al., 2014).

During the year 2013-14, 865 serum samples were screened by c-ELISA for studies on seroprevalence of bluetongue in Hyderabad. The samples screened gave a positive result of $82 \%$ in sheep, $86.2 \%$ in bovine and $62.7 \%$ in goat (Anon, 2014).

\section{Sero-epidemiology of eastern and north-eastern states of India}

Blood samples were collected from susceptible animals, viz. sheep, goat and cattle of different eastern and North Eastern (NE) states, viz. Jharkhand, West Bengal, Meghalaya, Assam, Manipur, Nagaland and Mizoram. Sera were separated and stored at $-20{ }^{\circ} \mathrm{C}$. Serum samples were screened by i-ELISA using one laboratory developed i-ELISA based kit. This kit is developed and standardized by Mukteswar centre of All India Neteork Programme on Bluetongue (AINP-BT) scheme of Indian Council of Agricultural Research- Indian Veterinary Research Institute (ICAR-IVRI), Mukteswar campus, Nainital (Uttarakhand). The standardized procedure was described elsewhere (Joardar et al., 2013; Panda et al., 2011). Diluted VP-7 based recombinant BTV group specific antigen was used for coating the plates. Anti-species,

Table 1 Seroprevalence of anti-BTV antibodies among West Bengal animaals

\begin{tabular}{llll}
\hline Species & $\begin{array}{l}\text { Number of samples } \\
\text { collected \& tested }\end{array}$ & $\begin{array}{l}\text { Number of } \\
\text { positive samples }\end{array}$ & $\begin{array}{l}\text { Percent (\%) } \\
\text { positivity }\end{array}$ \\
\hline Sheep & 1064 & 440 & 41.35 \\
Goat & 1307 & 613 & 46.90 \\
Cattle & 377 & 137 & 36.33 \\
Overall & 2748 & 1190 & 43.30 \\
\hline
\end{tabular}


Table 2 Seroprevalence of anti-BTV antibodies among Bihar animals

\begin{tabular}{llccc}
\hline Animal species & Name of the district & $\begin{array}{l}\text { Number of sample collected and } \\
\text { tested }\end{array}$ & $\begin{array}{l}\text { Number of positive } \\
\text { samples }\end{array}$ & positivity \\
\hline Sheep & Begusarai & 41 & 28 & 68.29 \\
Goat & Bhagalpur & 99 & 31 & 31.93 \\
& Gaya & 80 & 19 & 23.75 \\
Cattle & Begusarai & 65 & 53 & 81.54 \\
Buffalo & Purnia & 30 & 14 & 46.66 \\
Total & & 315 & 145 & 46.03 \\
\hline
\end{tabular}

viz. anti-sheep, anti-goat, anti-cattle horse radish peroxidae coupled secondary immunoconjugates were used for detecting the polyclonal antibodies of the animal sera.

A total of 7346 animal serum samples (sheep-2147, goat- 3290, cattle- 1844 and mithun-35, buffalo-30) were tested for sero-monitoring to detect anti-BTV antibodies. The test sera were collected from different parts of West Bengal, Bihar, Orissa, Jharkhand, Sikkim, Assam, Meghalaya, Nagaland, Manipur, Mizoram and Tripura. Out of the total samples tested, 3065 samples (sheep- 797, goat1369 , cattle- 1844, buffalo-14 \& mithun-19) were found positive to anti-BTV antibodies. The percent (\%) positivity of animals includes sheep-37.12, goats-41.61, cattle46.96, mithun-54.28 and buffalo-46.66.

The state-wise results are described below-

\section{West Bengal}

Total 2748 serum samples (sheep-1064, goat-1307, cattle-377) were collected from different districts (agro-climatic zones) of West Bengal and tested subsequently. The results showed $41.35 \%$ sheep, $46.90 \%$ goat and $36.33 \%$ ) serum samples were positive (Table 1 ). These results are summation of certain previous reports documented from the laboratory of AINP-BT, Kolkata centre (Biswas et al., 2009; Chakrabarti et al., 2007; Halder et al., 2016; Mandal et al., 2011; Panda et al., 2011).

\section{Bihar}

Out of 315 serum samples (41 sheep, 179 goat, 65 cattle \& 30 buffalo) screened for anti-BT antibodies, an overall sero-prevalence of $68.29 \%, 27.93 \%, 81.54 \%$ and $46.66 \%$ was observed in sheep, goats, cattle and buffaloes, respectively (Table 2) [un-published data].

District-wise distribution of goat serum samples along with their assessment of anti-bluetongue antibodies are depicted in the Table 2. Highest seropositivity was observed in cattle followed by sheep, buffaloes and goats.

\section{Jharkhand}

Out of total 480 animal serum samples (sheep-190, goats-210 and cattle-80) screened in Jharkhand, $43.68 \%$
Table 3 Seroprevalence of anti-BTV antibodies among Jharkhand animals

\begin{tabular}{llcl}
\hline Species & $\begin{array}{l}\text { Number of samples } \\
\text { collected and tested }\end{array}$ & $\begin{array}{l}\text { Number of } \\
\text { positive samples }\end{array}$ & $\begin{array}{l}\text { Percent (\%) } \\
\text { positivity }\end{array}$ \\
\hline Sheep & 190 & 83 & 43.68 \\
Goat & 210 & 91 & 43.33 \\
Cattle & 80 & 46 & 57.50 \\
Total & 480 & 220 & 45.83 \\
\hline
\end{tabular}

Table 4 Seroprevalence of anti-BTV antibodies among Orissa animals

\begin{tabular}{llcl}
\hline Species & $\begin{array}{l}\text { Number of samples } \\
\text { collected and tested }\end{array}$ & $\begin{array}{l}\text { Number of } \\
\text { positive samples }\end{array}$ & $\begin{array}{l}\text { Percent (\%) } \\
\text { positivity }\end{array}$ \\
\hline Sheep & 120 & 32 & 26.66 \\
Goat & 112 & 35 & 31.25 \\
Cattle & 132 & 69 & 52.27 \\
Overall & 364 & 136 & 37.36 \\
\hline
\end{tabular}

of sheep, $43.33 \%$ of goat and $57.50 \%$ of cattle sera were found positive (Table 3 ). The $\%$ positivity ranged between 41 and $51 \%$ in different agro-climatic zones. The results showed slight higher seroprevalence in cattle than sheep and goats in different agro climatic zones of Jharkhand.

The incidence of BT not detected officially, so far, the present seroprevalence status of BT in Jharkhand indicates presence of $\mathrm{BT}$ infection in the state for the first time (Tigga et al., 2015a, b).

\section{Orissa}

Out of total 364 animal serum samples screened (sheep120, goat-112 and cattle-132) in different districts of Orissa, viz. Cuttack, Mayurbhanj, Khurdah and Bhubaneswar, $26.66 \%$ of sheep, $31.25 \%$ of goat and $52.27 \%$ of cattle serum samples were found positive for the presence of anti-BTV antibodies (Table 4). The results showed slight higher seroprevalence in cattle than goats and sheep in different districts of Orissa. Outbreak/incidence of BT in animals not being reported in Orissa, the study indicated 
Table 5 Seroprevalence of anti-BTV antibodies among Sikkim animals

\begin{tabular}{lccl}
\hline Species & $\begin{array}{l}\text { Number of samples } \\
\text { collected and tested }\end{array}$ & $\begin{array}{l}\text { Number of } \\
\text { positive samples }\end{array}$ & $\begin{array}{l}\text { Percent (\%) } \\
\text { positivity }\end{array}$ \\
\hline Sheep & 49 & 9 & 18.36 \\
Goat & 200 & 105 & 52.50 \\
Cattle & 81 & 63 & 77.77 \\
Total & 330 & 177 & 53.63 \\
\hline
\end{tabular}

Table 6 Seroprevalence of anti-BTV antibodies among Assam animals

\begin{tabular}{llll}
\hline Species & $\begin{array}{l}\text { Number of samples } \\
\text { collected and tested }\end{array}$ & $\begin{array}{l}\text { Number } \\
\text { of positive } \\
\text { samples }\end{array}$ & Positivity (\%) \\
\hline Sheep & 204 & 120 & 58.82 \\
Goat & 355 & 94 & 26.47 \\
Cattle & 170 & 103 & 60.58 \\
Total & 729 & 317 & 43.48 \\
\hline
\end{tabular}

presence circulating BTV in the state (Joardar et al., 2014).

\section{Sikkim}

A total of 330 serum samples (49 sheep, 200 goat and 81 cattle) screened for anti-BTV antibodies showed an overall sero-prevalence of $53.63 \%$.

The species-wise seropositivity for anti-BTV antibodies found was $18.36 \%, 52.50 \%$ and $77.77 \%$ in sheep, goat and cattle, respectively. Species-wise distribution of serum samples along with their assessment of anti-bluetongue virus antibodies are depicted in the Table 5.

Earlier, seroprevalence of bluetongue in goats and cattle of Sikkim was reported indicating presence of potent vector midges and circulating bluetongue virus (BTV) in the state (Ramudamu et al., 2017).

\section{Assam}

Out of total 729 serum samples (sheep-204, goat-355, cattle-170) screened, $58.82 \%$ of sheep, $26.47 \%$ of goat and $60.58 \%$ of cattle serum samples were found positive (Table 6). Presence of anti-bluetongue virus antibodies was found highest in cattle population followed by sheep and goat. The prevalence in different agro climatic zones ranged between 30-50\%. Incidence of bluetongue in animals of Assam being not reported so far; the present seroprevalence status of bluetongue in Assam indicates presence of sub-clinical infection in the state for the first time (Joardar et al., 2013).
Table 7 Seroprevalence of anti-BTV antibodies among Meghalaya animals

\begin{tabular}{llll}
\hline Species & $\begin{array}{l}\text { Number of samples } \\
\text { collected and tested }\end{array}$ & $\begin{array}{l}\text { Number of } \\
\text { positive samples }\end{array}$ & $\begin{array}{l}\text { Percent (\%) } \\
\text { positivity }\end{array}$ \\
\hline Sheep & 147 & 43 & 29.25 \\
Goat & 188 & 114 & 60.63 \\
Cattle & 367 & 168 & 45.77 \\
Total & 702 & 325 & 46.29 \\
\hline
\end{tabular}

Table 8 Seroprevalence of anti-BTV antibodies among Manipur animals

\begin{tabular}{llll}
\hline Species & $\begin{array}{l}\text { Number of samples } \\
\text { collected and tested }\end{array}$ & $\begin{array}{l}\text { Number of } \\
\text { positive samples }\end{array}$ & $\begin{array}{l}\text { Percent (\%) } \\
\text { positivity }\end{array}$ \\
\hline Sheep & 332 & 70 & 21.08 \\
Goat & 603 & 208 & 34.49 \\
Cattle & 502 & 196 & 39.04 \\
Total & 1437 & 474 & 32.98 \\
\hline
\end{tabular}

\section{Meghalaya}

A total of 702 (sheep-147, goat-188, cattle-367) serum samples were collected from different districts (agro-climatic zones) of Meghalaya and tested subsequently. Forty three $29.25 \%$ sheep, $60.63 \%$ goat and $45.77 \%$ cattle were found to possess anti-BTV antibodies. Presence of antibluetongue antibodies was found highest in goat population followed by cattle and sheep (Table 7).

The study reported first time the sero-prevalence status of bluetongue in Meghalaya which might indicate the presence of circulating bluetongue virus in the state (Nongdhar et al., 2017).

\section{Manipur}

Out of total 1437 animal serum samples screened (sheep332, goat-603 cattle-502) in Manipur, $21.08 \%$ of sheep, $34.49 \%$ of goat and $39.04 \%$ of cattle serum samples were found positive. This study revealed seroprevalence of bluetongue in cattle, goats and sheep of Manipur in descending order (Table 8).

Earlier also seroprevalence of sheep was reported lower than cattle and goats (Joardar et al., 2012).

\section{Tripura}

Out of total 195 samples (goat- 136 and cattle- 59) collected and tested from Tripura, $43.88 \%$ goat and $42.37 \%$ cattle were found to possess anti-BTV antibodies (Table 9).

This study revealed seroprevalence of bluetongue in goats and cattle of Tripura in descending order. The present study reported sero-prevalence status of bluetongue 
Table 9 Seroprevalence of anti-BTV antibodies among Tripura animals

\begin{tabular}{lcll}
\hline Species & $\begin{array}{l}\text { Number of samples } \\
\text { collected \& tested }\end{array}$ & $\begin{array}{l}\text { Number of } \\
\text { positive samples }\end{array}$ & $\begin{array}{l}\text { Percent } \\
\text { (\%) } \\
\text { positivity }\end{array}$ \\
\hline Goat & 136 & 59 & 43.38 \\
Cattle & 59 & 25 & 42.37 \\
Total & 195 & 13 & 43.07 \\
\hline
\end{tabular}

Table 10 Seroprevalence of anti-BTV antibodies among Mizoram animals

\begin{tabular}{llll}
\hline Species & $\begin{array}{l}\text { Number of samples } \\
\text { collected and tested }\end{array}$ & $\begin{array}{l}\text { Number of } \\
\text { positive samples }\end{array}$ & $\begin{array}{l}\text { Percent } \\
\text { (\%) } \\
\text { positivity }\end{array}$ \\
\hline Cattle & 11 & 6 & 54.54 \\
Total & 11 & 6 & 54.54 \\
\hline
\end{tabular}

Table 11 Seroprevalence of anti-BTV antibodies among Mithun of Nagaland

\begin{tabular}{llcl}
\hline $\begin{array}{l}\text { Types of animal } \\
\text { (Mithun) }\end{array}$ & $\begin{array}{l}\text { Samples } \\
\text { screened }\end{array}$ & No. positive & Positivity (\%) \\
\hline Male & 22 & 8 & 36.36 \\
Female & 28 & 11 & 39.28 \\
$<2$ years old & 24 & 9 & 37.50 \\
$>2$ years old & 26 & 10 & 38.46 \\
Total & 50 & 19 & 38.00 \\
\hline
\end{tabular}

in Tripura, for the first time, indicating presence of BT infection in the state (Joardar et al., 2016).

\section{Mizoram}

From Mizorum, cattle samples were collected from animal farm of Veterinary College, CAU, Aizawl and subsequently tested by ELISA. Out of 11 samples tested, 6 were found positive (54.54\%) (Table 10) [Un-published data].

\section{Nagaland}

Out of total 50 Mithin (Bos frontalis) serum samples of Nagaland screened, 19 serum samples (38\%) were found positive for the presence of anti-BTV antibodies. In the present study, \% positivity found $36.36 \%$ and $39.26 \%$ in male and female animals, respectively. Again animals of age $<2$ years had \% positivity of 37.50 , but animals of age $>2$ years had $38.46 \%$ sero-positivity. The difference in $\%$ positivity between male and female or due to age variation was not significant at two degree of freedom (5\%) (Table 11).

The study indicates presence of bluetongue virus in Nagaland that warrants further studies on potent vectors and BTV serotypes circulating in the state (Joardar et al., 2015).

\section{Isolation of BTV from eastern part of India}

With the aim of exploring the bluetongue epidemiology, attempts were made to isolate bluetongue virus (BTV) from blood collected from sheep and goats of different areas of West Bengal, Jharkhand, Assam.

\section{Sheep samples}

A total of 13 blood samples were collected from Maidan pasture area of Kolkata, West Bengal. Two samples were confirmed by AINP-BT, Hisar centre as BTV-15 and BTV-21 (Joardar et al., 2009).

Incidentally, BTV-21 has not been previously reported or isolated from anywhere on the Indian subcontinent. BTV isolates in India have previously come from infected sheep in areas affected by outbreaks. However, the two isolates described here were obtained from sheep grazing pasture in Kolkata Maidan, a region of the Indian subcontinent that is not considered to be affected by bluetongue. Sheep grazing in Kolkata Maidan are usually brought from different areas of Rajasthan, Gujarat and Uttar Pradesh states, for selling in the local meat markets of Kolkata or for rearing in villages in various districts of West Bengal. This might be a route of entry for strains of BTV from the northern and western states of India to West Bengal. As the eastern and north-eastern states contain large numbers of sheep that are susceptible to BTV infection, there is a potential for exotic strains of BTV to affect sheep in these areas.

\section{Goat samples}

The animals (of north 24 pgs district of West Bengal) showing characteristic symptoms of BT during the time of collection were used for BTV isolation. The sample (WB/G/13), generarted from goat blood, producing CPE in BHK-21 cell line was considered as viral isolate.

The overall findings in embryonated chicken eggs, cell line and RNA PAGE indicated that the suggestive sample (WB/G/13) was actually a positive sample of BTV.

Then dsRNA extracted from infected BHK-21 cell line was further used for confirmation of BTV isolate using molecular tools viz. RT-PCR using primers of NS1 and NS3 genes. The molecular characterisation of BTV isolate was done targeting the VP2 gene for sequence based serotyping. In this study, the sequence report of the plasmid product of the isolate $(\mathrm{WB} / \mathrm{G} / 13)$ confirmed that the isolated virus from goat was of actually BTV-16 (un-published data).

\section{Vector (Culicoides midges)}

Each batch of non-engorged midges was pooled to prepare individual sample. The samples $(n=3)$ each 
Table 12 Habitat of collected Culicoides

\begin{tabular}{lll}
\hline Identified species of Culicoides & Sex & Habitat \\
\hline $\begin{array}{l}\text { Culicoides (Oecacta) schultzei (Enderlein) } \\
\text { Culicoides (Oecacta) schultzei (Enderlein) }\end{array}$ & Male & Animal shed, open drain, cow dung, saline soil by the side of river \\
$\begin{array}{l}\text { Culicoides oxystoma } \\
\text { Culicoides oxystoma }\end{array}$ & Male & Animal shed, manger, cracked walls, cow dung, biogas plant near cattle shed \\
Culicoides definitus & Female & Animal shed, mud, bush, holes of tree trunk \\
Culicoides definitus & Male & Cow dung, byre, manger, cracked walls of animal shed \\
Culicoides kamrupi & Female & Animal shed \\
Culicoides kamrupi & Male & Animal shed, mud, bush \\
Culicoides actoni & Female & Cow dung, byre, manger, cracked walls \\
Male & Male & Water logged ditches and decomposed manure, open drain \\
Culicoides actoni & & \\
C. inornatithorax & Female & Walls of cattle shed (wooden plank, roof thatch) \\
C. inornatithorax & Male & Water logged ditches and decomposed manure on the back of the animal shed \\
\hline
\end{tabular}

numbering up to 200 midges were considered for BTV isolation. This BHK-21 cell lysate sample (CCS-1) was chosen for further processing. Polyacrylamide gel electrophoresis of extracted RNA of the suggestive sample (CCS-1) showed 10-segmented profile, characteristic of BTV. A band corresponding to $274 \mathrm{bp}$ was obtained in agarose gel when RT-PCR was performed using NS1 specific primers. Subsequently, the isolate was serotyped as BTV-16 by Hissar centre of AINP-BT (Halder et al., 2013).

\section{Vector biology Morphology of Culicoides}

Haematogenous flies collected upon sweeping (using mechanical fly trappers) from time to time were sent to Diptera section, Zoological Survey of India (ZSI), New Alipore, Kolkata for morphological identification of Culicoides midges up to species level. Several species of Culicoides were identified in eastern Indian states based on morphological characteristics viz. wing vein, genital structure. Six predominant species were identified from different districts of West Bengal, viz. Culicoides actoni, C. clavipalpis, C. oxystoma, C. anophelis, C. palpifer and C. alatus (Biswas et al., 2011; Halder et al., 2013), C. innoxius, C. peregrines, C. fulvus (Anon, 2016). Two species of Culicoides were identified from six districts of Assam, viz. Culicoides schulzei and C. kamrupi (Barkataki et al., 2012). C. oxystoma was considered as predominant species in various districts of Jharkhand (Tigga et al., 2015a, b) and C. actoni along with C. inornatithorax were found in Meghalaya (Nongdhar, 2015).

\section{Habitat of the Culicoides}

Habitat of Culicoides midges was observed at different districts of West Bengal, Assam, Jharkhand, Meghalaya during 2011-2015. Mostly midges are observed at animal shed, cow dung, nearby wet areas of animal shed etc. (Table 12) (un-published data).

\section{Conclusions}

Since bluetongue disease is an outcome of the interaction of virus, susceptible hosts and competent vectors (Culicoides spp.), the complex inter-relation should be studied more vividly to reveal the comprehensive epidemiology of the disease. All the epidemiological components of BT are present in eastern and north-eastern parts of India that warrants presence of the disease in these parts too. Hence, further surveillance and preparedness are recommended to avoid future BT outbreak, if any.

\section{Abbreviations \\ AINP-BT: All India Network Programme on Bluetongue; AGID: Agar Gel Immu- nudiffusion; AGPT: Agar Gel Immuno-precipitation Test; BT: Bluetongue; BT: Bluetongue virus; CELISA: Competitive Enzyme Linked Immunosorbent Assay; iELISA: Indirect Enzyme Linked Immunosorbent Assay; I.C.A.R.: Indian Council of Agricultural Research O.D.: Optical Density; WBUAFS: West Bengal University of Animal and Fishery Sciences.}

\section{Acknowledgements}

Funds provided by the Indian Council of Agricultural Research (I.C.A.R.), New Delhi to carry out the research work is thankfully acknowledged. Thanks are due to the Vice Chancellor, West Bengal University of Animal and Fishery Sciences, Kolkata, for providing necessary infrastructural facilities to carry out the work. The Author acknowledges the contributions of his colleagues, viz. Prof. Amalendu Chakrabarti and Professor Chandan Lodh \& Research Associates and students of the Bluetogue laboratory of WBUAFS.

\section{Authors' contributions}

The author supervised the work, analysed the results and wrote the manuscript.

\section{Funding}

Indian Council of Agricultural Research (I.C.A.R.), New Delhi funded [F. No. 3(8)/98 ASR-IV] scheme All India Network Programme on Bluetongue (AINP-BT). 


\section{Availability of data and materials}

All the data and materials used to reach the conclusion of this study are available from the corresponding author on reasonable request.

\section{Declarations}

Ethics approval and consent to participate

Not applicable.

\section{Consent for publication}

Not applicable.

\section{Competing interests}

The Author declare that there is no competing interests.

Received: 23 September 2020 Accepted: 12 February 2022 Published online: 03 March 2022

\section{References}

Abera, T., Bitew, M., Gebre, D., Mamo, Y., Deneke, Y., \& Nandi, S. (2018). Bluetongue disease in small ruminants in south western Ethiopia: Crosssectional sero-epidemiological study. BMC Research Notes, 11, 112-117.

Anon. (2006). Annual report of All India Network Programme on Bluetongue for 2005-06 (p. 38). Indian Council of Agriculture and Research.

Anon. (2008a). Annual report of All India Network Programme on Bluetongue for 2007-08 (pp. 36). Indian Council of Agriculture and Research.

Anon. (2008b). Annual report of All India Network Programme on Bluetongue for 2007-08 (pp. 46, 47). Indian Council of Agriculture and Research.

Anon. (2014). Annual Report of All India Network Programme on Bluetongue (AINP-BT) for 2013-14. Indian Council of Agriculture and Research, pp. $\mathrm{xvi}$.

Anon. (2016). Annual report of All India Network Programme on Bluetongue (AINP-BT) for 2015-16 (pp. xx). Indian Council of Agriculture and Research.

Attoui, H., Maan, S. S., Anthony, S. J., \& Mertens, P. P. C. (2009). Bluetongue virus, other orbiviruses and other reoviruses: Their relationships and taxonomy (1st ed., p. 23). Elsevier/Academic Press.

Barkataki, B., Joardar, S. N., Parui, P., Samanta, I., \& Isore, D. P. (2012). Collection and identification of Culicoides midges in Assam. Indian Journal of Animal Health, 51(2), 121-124.

Bianchi, R. M., Panziera, W., Faccin, T. C., deAlmeida, G. L., Cargnelutti, J. F., Flores, E. F., Kommers, G. D., \& Fighera, R. A. (2017). Clinical, pathological and epidemiological aspects of outbreaks of bluetongue disease in sheep in the central region of Rio Grande do Sul. Pesquisa Veterinaria Brasileira, $37(12), 1442-1452$.

Biswas, M., Joardar, S. N., Samanta, I., Isore, D. P., \& Aich, R. (2009). Seroprevalence of bluetongue in different species of animals in West Bengal: Present scenario. Indian Journal of Animal Health, 48(1), 43-46.

Biswas, M., Joardar, S. N., Samanta, I., Isore, D. P., Aich, R., \& Parui, P. (2011). Conducive environment for propagation of potent bluetongue vector exists in West Bengal. Indian Journal of Animal Health, 50(2), 46-48.

Bitew, M., Nandi, S., Ravishankar, C., \& Somvanshi, R. (2013). Serological and molecular evidence of bluetongue in sheep and goats in Uttar Pradesh, India. African Journal of Biotechnology, 12(19), 2699-2705.

Boyer, T. C., Ward, M. P., Wallace, R. L., \& Singer, R. S. (2007). Regional seroprevalence of bluetongue virus in cattle in Illinois and western Indiana. American Journal of Veterinary Research, 68, 1212-1219.

Casaubon, J., Chaignat, V., Vogt, H. R., Michel Adam, O., Thür, B., \& Ryser-Degiorgis, M. (2013). Survey of bluetongue virus infection in free-ranging wild ruminants in Switzerland. BMC Veterinary Research, 9, 166.

Chakrabarti, A., Lodh, C., Joardar, S. N., \& Aich, R. (2007). Seroprevalence of bluetongue in West Bengal-current status. Indian Journal of Comparative Microbiology Immunology and Infectectious Dieases, 28, 63-64.

Chand, K., Biswas, S. K., Pandey, A. B., Muthuchelvan, D., \& Mondal, B. (2014). Bluetongue in India: A review. Advances in Animal and Veterinary Sciences, 3(11), 605-612.

Chandel, B. S., Chauhan, H. C., \& Kher, H. N. (2003). Comparison of the standard AGID test and competitive ELISA for detecting bluetongue virus antibodies in camels in Gujrat, India. Tropical Animal Health Products, 35, 99-104.

Chang, G., Yamin, L., Shao, C., Xu, S. B. \& Zheng, T. R. (1995). Epidemiological investigations and control of bluetongue disease in Jianshu Province, China. ACIAR Proceedings., No. 66

Clavijo, A., Sepulveda, L., Riva, J., Pessoa Silva, M., Tailor Ruthes, A., \& Lopez, J.W. (2012). Isolation of bluetongue virus serotype 12 from an outbreak of the disease in South America. Veterinary Record, 151, 301-302.

Coetzee, P., Stokstad, M., Venter, E. H., Myrmel, M., \& Vuuren, M. V. (2012). Bluetongue: An historica and epidemiological perspective with the emphasis of South Africa. Journal of Virology, 9, 198-206.

Dayakar, S., Sreenivasulu, D., Sudharani, K., Subba Rao, M. V., \& Sreenivasulu, P. (2001). Serological survey for the prevalence of bluetongue virus antibodies in cattle by competitive enzyme linked immunosorbent assay. Indian Journal of Animal Sciences, 71(7), 614-616.

De, A., Batabyal, S., Biswas, S. K., Chand, K., Singh, R. K., \& Mondal, B. (2008). Surveillance of bluetongue virus antibody in goats using a recombinant VP7-based indirect ELISA in the coastal saline area of West Bengal, India. Veterinaria Itallana, 45, 339-346.

Dulac, G. C., Dubuc, C., Myers, D. J., Afshar, A., Taylor, E. A., Ward, D., \& Sterritt, W. (1989). Incursion of bluetongue virus type 11 and epizootic hemorrhagic disease of deer type 2 for two consecutive years in the Okanagan Valley. Canadian Veterinary Journal, 30, 351.

Elbers, A. R. W., Popma, J., Oosterwolde, S., van Rijn, P. A., Vellema, P., \& van Rooij, E. M. A. (2008). A cross-sectional study to determine the seroprevalence of bluetongue virus serotype 8 in sheep and goats in 2006 and 2007 in the Netherlands. BMC Veterinary Research, 4, 33.

Francisco, R. F., Reyes-Garcia, A. R., Alcalde, V., \& Christian, G. (2008). Spatial and temporal evolution of bluetongue virus in wild ruminants, Spain. Emerging Infectious Diseases, 4, 951-953.

Gambles, R. M. (1949). Bluetongue of sheep in Cyprus. Journal of Comparative Pathology, 59, 176-190.

Halder, A. (2011). Isolation of bluetongue virus from Culicoides schultzei visà-vis exploring the role of vector in sub-clinical bluetongue infection in ruminants of West Bengal. Master degree thesis submitted to West Bengal University of Animal Fishery Sciences, Kolkata.

Halder, A., Joardar, S. N., Parui, P., Banerjee, D., Kumar, V., Samanta, I., \& Lodh, C. (2013). Prevalence of midges: Potent vectors for bluetongue virus infection in West Bengal, India. Advances in Veterinary and Animal Sciences, $1(4 S), 45-60$.

Halder, A., Joardar, S. N., Isore, D. P., Samanta, I., Parui, P., Banerjee, D., \& Lodh, C. (2016). Seroepidemiology of bluetongue in South Bengal. Veterinary World, 9(1), 1-5.

Harbola, P. C., Choudhary, P. G., Lalkrishna, Sirruguppi, B. S., \& Kole, R. S. (1982). Incidence of bluetongue in sheep in Maharastra. Indian Journal of Comparative Microbiology Immunology and Infectious Diseases, 3, 121-127.

Hemadri, D., Maan, S., Chanda, M. M., Rao, P. P., Putty, K., Krishnajyothi, Y., Reddy, G. H., Kumar, V., Batra, K., Reddy, Y. V., Man, N. S., Reddy, Y. N., Singh, K. P., Shivachandra, S. V., Hegde, N. R., Rahman, H., \& Martens, P. P. C. (2017). Dual infection with bluetongue virus serotypes and first-time isolation of serotype 5 in India. Transboundary and Emerging Diseases, 64(6), 1912-1917.

Henning, M. W. (1949). Blue-tongue, blou-tong. Animal diseases in South Africa (2nd ed.). Central News Agency Ltd.

Hoffmann, B., Saberath, M., Thalheim, S., Bunzenthal, C., Strebelow, G., \& Beer, M. (2008). Bluetongue virus serotype 8 re-emergence in Germany, 2007 and 2008. Emerging Infectious Diseases, 14(9), 1421-1423.

Hofmann, M. A., Renzullo, S., Mader, M., Chaignat, V., Worwa, G., \& Thuer, B. (2008). Genetic characterization of toggenburg orbivirus, a new bluetongue virus, from goats, Switzerland. Emerging Infectious Diseases, 14(12), 1855-1861.

Hugh-Jones, M. E., Taylor, W. P., Jones, F., Luther, G., Miller, J., Karns, P., \& Hoyt, P. (1989). Serological observations on the epidemiology of bluetongue infection in Louisiana. Preventive Veterinary Medicine, 7, 11-18.

Inaba, Y., Ishii, S., \& Omori, T. (1966). Bluetongue like disease in Japan. Bulletin De L'office International Des Epizooties, 66, 329-340.

Ishitani, R. (1967). Lesions and the pathological different diagnosis of a bluetongue like disease in cattle. Journal of Japanese Veteterinary Medcal Association, 20, 219-228. 
Jain, N. C., Gupta, Y., \& Prasad, G. (1992). Bluetongue virus antibodies in buffaloes and cattle in Haryana state of India. Revue Scientifique Et Technique 11, 699-711.

Joardar, S. N., Lodh, C., Chakrabarti, A., Bakshi, S., \& Aich, R. (2009). Isolation of bluetongue virus serotypes 15 and 21 in West Bengal, India. Veterinary Record, 165, 751-752.

Joardar, S. N., Singh, N. I., Barkataki, B., Lodh, C., Chakraborty, A., \& Pradhan, A. (2012). Seroprevalence of bluetongue in ruminants of Manipur. Indian Journal of Comparative Microbiology Immunology and Infectious Diseases, 33(1\&2), 54-56.

Joardar, S. N., Barkataki, B., Halder, A., Lodh, C., \& Sarma, D. (2013). Seroprevalence of bluetongue in north eastern Indian state-Assam. Veterinary World, 6(4), 196-199.

Joardar, S. N., Halder, A., Maity, A., Mishra, S. K., \& Lodh, C. (2014). Seroprevalence of bluetongue in ruminants of Orissa. Indian Journal of Comparative Microbiology Immunology and Infectious Diseases, 35(2), 58-60.

Joardar, S. N., Mukherjee, S., Lodh, C., Halder, A., \& Mukherjee, A. (2015). Seroprevalence of bluetongue in free-range mithuns (Bos frontalis). Advances in Animal and Veterinary Sciences, 3(9), 500-502. https://doi. org/10.14737/journal.aavs/2015/3.9.500.502

Joardar, S. N., Halder, A., Lodh, C., Mahanti, A., \& Barui, A. (2016). Seroprevalence of bluetongue in ruminants of Tripura. Indian Journal of Animal Health, 55(2), 161-166.

Kakker, N. K., Prasad, G., Bhatnagar, P., \& Srivastava, R. N. (2002). Sero-prevalence of bluetongue virus infection in cattle in Haryana, Himachal Pradesh, Punjab and Rajasthan. Indian Journal of Comparative Microbiology and Infectious Diseases, 23, 147-151.

Khezri, M., \& Azimi, S. M. (2013a). Seroprevalence of bluetongue disease in sheep in west and northwest provinces of Iran. Veterinary Research Forum, 4(3), 195-198.

Khezri, M., \& Azimi, S. M. (2013b). Epidemiological investigation of bluetongue virus antibodies in sheep in Iran. Veterinary World, 6(3), 122-125.

Komorov, A., \& Goldsmit, L. (1951). A BT like disease of cattle and sheep in Israel. Refuah Veterinary, 8, 96-100.

Kulkarni D. O., Bannilikar, A. S., Karpe, A. S., Gujar, M. B., \& Kulkarni, M. N. (1992), Epidemiological observations on bluetongue in sheep in marathwada region of Maharashtra state of India. In T. E. Walton \& B. I. Osburn (Eds.), Bluetongue, African Horse Sickness and Related Orbiviruses (pp. 193-196). Boca Raton, Florida, USA.

Lager, I., Duffy, S., Miquet, J., Vagnozzi, A., Gorchs, C., Draghi, M., Cetra, B., Soni, C., Hamblin, C., Maan, S., Samuel, A. R., Mertens, P., Ronderons, M., \& Ramirez, V. (2004). Incidence and isolation of bluetongue virus infection in cattle of the SantoTomé Department, Corrientes Province, Argentina. Veterinaria Itaiana, 40(3), 141-144.

Legisa, D., Gonzalez, F., De Stefano, G., Pereda, A., \& Dus Santos, M. J. (2013). Phylogenetic analysis of bluetongue virus serotype 4 field isolates from Argentina. Journal of General Virology, 94, 652-662.

Linden, A., Mousset, B., Grégoire, F., Hanrez, D., Vandenbussche, F., Vandemeulebroucke, E., Vanbinst, T., Verheyden, B., \& Clerck, K. D. (2008). Bluetongue virus antibodies in wild red deer in southern Belgium. Veterinary Record, 162(14), 459.

Maan, S., Maan, N. S., Nomikou, K., Batten, C., Antony, F., \& Belaganahalli, M. N. (2011). Novel bluetongue virus serotype from Kuwait. Emerging Infectious Diseases, 17, 886-889.

Maan, S., Maan, N. S., Ross-smith, N., Batten, C. A., Shaw, A. E., Anthony, S. J., Samuel, A. R., Darpel, K. E., Veronesi, E., Oura, C. A., Singh, K. P., Nomikou, K., Potgieter, A. C., Attoui, H., van Rooij, E., van Rijn, P., De Clercq, K., Vandenbussche, F., Zientara, S., ... Mertens, P. P. (2008). Sequence analysis of bluetongue virus serotype 8 from the Netherlands 2006 and comparison to other European strains. Virology Journal, 377, 308-318.

MacLachlan, N. J., \& Dubovi, E. J. (2011). Fenner's veterinary virology (p. P283). Academic Press.

Mahajan, N. K., Prasad, G., Jain, N. C., Dhanoea, J. S., \& Gupta, Y. (1991). Epizootiological studies on bluetongue at an organized sheep breeding farm near Hissar, Haryana. Indian Journal of Animal Sciences, 61, 1-5.

Mahmoud, M. A., \& Khafagi, M. H. (2014). Seroprevalence of bluetongue in sheep and goats in Egypt. Veterinary World, 7(4), 205-208.

Mandal, N., Joardar, S. N., Samanta, I., \& Isore, D. (2012). Development of userfriendly diagnostic tool to detect anti-bluetongue antibodies. Indian Journal of Animal Health, 51(2), 63-68.
Mandal, N., Mondal, A., \& Joardar, S. N. (2011). Indigenous diagnostic approach for detection of bluetongue disease in West Bengal, India. Global Veterinaria, 7(3), 230-233.

Manso-Ribiero, J., \& Noronha, F. M. O. (1957). Five catarrhale due mouton au Portugal (Bluetongue). Bulletin De L'office International Des Epizooties, 50, 46-64.

Mehrotra, M. L., \& Shukla, D. C. (1984). Seroprevalence of bluetongue virus in sheep, cattle, buffaloes in India. Indian Journal of Animal Sciences, 54, 718.

Mehrotra, M. L., Singh, R., \& Shukla, D. C. (1991). Seroepidemiology and isolation of virus from and outbreak of bluetongue in Tamil Nadu. Indian Journal of Animal Sciences, 61, 1282-1283.

Mehrotra, M. L., Shukla, D. C. and Khanna, P. N. (1996). Studies on bluetongue disease in India-isolation and serotyping of field isolate. Indian Journal of Comparative Microbiology Immunology and Infectious Diseases, 17, $8-13$.

Mellor, P. S., \& Wittmann, E. J. (2002). Bluetongue virus in the Mediterranean Basin 1998-2001. Veterinary Journal, 164, 20-37.

Meroc, E., Faes, C., Herr, C., Staubach, C., Verheyden, B., Vanbinst, T., Vandenbussche, F., Hooyberghs, J., Aerts, M., Clercq, K. D., \& Mintiens, K. (2008). Establishing the spread of bluetongue virus at the end of the 2006 epidemic in Belgium. Veterinary Microbiology, 131, 133-144.

Mo, C. L., Thompson, L. H., Homan, E. J., Oviedo, M. T., Greiner, E. C., González, J., \& Sáenz, M. R. (1994). Bluetongue virus isolations from vectors and ruminants in Central America and the Caribbean. American Journal of Veterinary ResEarch, 55, 211-215.

Mondal, B., Bisht, B., Biswas, S. K., \& Chand, K. (2013). Bluetongue virus serotype-1 in goats in the Pithoragarh area of Uttarakahand, India. Veterinaria Italiana, 49(4), 375-380.

Naresh, A., \& Prasad, G. (1995). Relative superiority of CELISA for detection of bluetongue virus antibodies. Indian Journal of Experimental Biology, 33, $880-882$.

Nongdhar, R. (2015). Evaluating the prevalence of Bluetongue in the unexplored north-eastern state: Meghalaya. Master degree thesis submitted to West Bengal University of Animal Fishery Sciences, Kolkata.

Nongdhar, R., Isore, D. P., Joardar, S. N., Samanta, I., Batabyal, K., Dey, S., Lodh, C., \& Barui, A. (2017). Seroprevalence of Sheep, goats and cattle of Meghalaya. Indian Journal of Animal Health, 56(2), 197-202.

Oberoi, M. S., Singh, G., \& Kwatra, M. S. (1988). Serological evidences of bluetongue virus activity in cattle and buffalo population. Indian Journal of Virology, 4, 50-51.

Omori, T. (1961). Fievrs. Catarskale du mouton (Bluetongue). Bulletin- Office International Des Épizooties, 50, 1109-1117.

Panda, M. K., Mondal, A., \& Joardar, S. N. (2011). Seroprevalence of bluetongue virus in sheep, goat and cattle in West Bengal, India. Animal Science Reporter, 5(3), 105-110.

Potey, D. E., Ingle, V. C., Sivakumar, P., Kalorey, D. R., \& Yuvaraj, S. (2006). Seroprevalence of Bluetongue virus in goats in Nagpur District of Vidarbha Region. National Seminar on "Strategies for Control Of Bluetongue" ( $p$. 21).

Prasad, G., \& Srivastava, R. N. (1995). Epizootiology of bluetongue virus in particular reference to India. In G. Prasad \& R. N. Srivastava (Eds.), Bluetongue: Indian perspective (pp. 1-3). CCS HAU Press, CCS Haryana Agricultural University.

Prasad, G. (2000). Whither bluetongue research in India. Indian Journal of Microbiology, 40, 163-175

Purse, B. V., Mellor, P. S., Rogers, D. J., Samuel, A. R., Mertens, P. P., \& Baylis, M. (2005). Climate change and the recent emergence of bluetongue in Europe. Nature Reviews Microbiology, 3, 171-181.

Ramudamu, B., Nongdhar, R., Lodh, C., \& Joardar, S. N. (2017). Maiden report on seroprevalence of bluetongue in ruminants of Sikkim. Indian Journal of Animal Health, 56(2), 265-270.

Ravishankar, C., Krishnan Nair, G., Mini, M., \& Jayaprakasan, V. (2005). Seroprevalence of bluetongue virus antibodies in sheep and goats in Kerala State, India. Revue Scientifique Et Technique, 24, 953-958.

Ruiz-Fons, F., Reyes-Garcia, A. R., Alcaide, V., \& Gortazar, C. (2008). Spatial and temporal evolution of bluetongue virus in wild ruminants, Spain. Emerging Infectious Diseases, 14, 951-953.

Sapre, S. N. (1964). An outbreak of bluetongue in goats and sheep. Veterinary Review, 15, 78-80. 
Saravanabava, K. (1992). Studies on bluetongue virus in sheep. Ph.D. thesis, Tamil Nadu Veterinary and Animal Sciences University, Madras, India.

Savini, G., Goffredo, M., Monaco, F., Gennaro, M. A. D., Baldi, L., Santis, P. D., Meiswinkel, R., \& Caporale, V. (2005). Bluetongue virus isolations from midges belonging to the Obsoletus complex (Culicoides, Diptera: Ceratopogonidae) in Italy. Veterinary Record, 157, 133-139.

Sharma, M. M., Lonkar, P. S., Srivastva, C. P., Dubey, S. C., Maru, A., \& Kalra, D. B. (1985). Epidemiology of bluetongue in sheep at an organised farm in semi arid part of Rajasthan, India. Indian Journal of Comparative Microbiology, Immunology and Infectious Diseases, 6, 188-192.

Singer, R. S., Jessup, D. A., Gardner, T. A., \& Boyoe, W. M. (1997). Pathogen exposure patterns among sympatric populations of big horn sheep, mule, deer and cattle. Journal of Wildlife Diseases, 33, 377-382.

Singh, B., Anantwar, L.G. \& Samod, A. (1982). A severe outbreak of bluetongue in sheep in Maharastra. In National seminar on sheep and goat diseases (p. 16). Central Sheep Wool Research Institute, Avikanagar.

Singh, A., Agrawal, R., Singh, R., Singh, R. K., \& Pande, N. (2009). Indirect-ELISA based on recombinant Vp7 specific protein for sero-epidemiological investigation of Blue Tongue in small ruminants of Jammu province. Journal of Immunology and Immunopathology, 11, 52-55.

Spreull, J. (1905). Malarial catarrhal fever (bluetongue) of sheep in South Africa. Journal of Comparative Pathology and Theriogenology, 18, 321-337.

Srinivas, R. P., Moogi. V. M., Ananth. M., Gopal, T. \& Keshavamurthy, B. S. (1982). Bluetongue disease outbreaks among sheep and goats of Kamataka. In Central Sheep Wool Research Institute. Abstracts of national seminar on sheep and goat disease (pp. 14-20). Central Sheep Wool Research Institute, Avikanagar, Rajasthan.

Srivastava, R. N., Prasad, G., Kakker, N. K., \& Bhatnagar, P. (1995). Epizootiology of bluetongue virus in particular reference to India. In G. Prasad \& R. N. Srivastava (Eds.), Bluetongue: Indian perspective (pp. 1-3). ICCS HAU Press.

Sreenivasulu, D., Rao, M .V. S. \& Gard, G. P. (1996). Bluetongue viruses in India: a review. In: T. D. St. George \& P. Kegao (Eds.), Bluetongue disease in Southeast Asia and the Pacific. Proceedings of the First Southeast Asia and the Pacific Regional bluetongue Symposium, Greenlake Hotel, Kunming, P. R. China, 22-24 Aug 1995. ACIAR Proceedings No 66:15-20.

St. George, T. D., Cybinski, D. H., Della-Porta, A. J., McPhee, D. A., Wark, M. C., \& Bainbridge, M. H. (1980). The isolation of two bluetongue viruses from healthy cattle in Australia. Australian Veterinary Journal, 56, 562-563.

Saminathan, M., Singh, K. P., Khoraijiya, J. H., Dinesh, M., Vineetha, S., Maity, M., Rahman, A. F., Misri, J., Malik, Y. S., Gupta, V. K., Singh, R. K., \& Dhama, K. (2020). An updated review on bluetongue virus: Epidemiology, pathology, and advances in diagnosis and control with special reference to India. Veterinary Quarterly, 40, 258-321.

Thiry, E., Saegerman, C., Guyot, H., Kirten, P., Losson, B., Rollin, F., Bodmer, M., Czaplicki, G., Toussaint, J. F., Clercq, K. D., Dochy, J. M., Dufey, J., Gilleman, J. L., \& Messeman, K. (2006). Bluetongue in northern Europe. Veterinary Record, 159, 327.

Tigga, P., Joardar, S. N., Halder, A., Lodh, C., Samanta, I., Isore, D. V., Batabyal, K., \& Dey, S. (2015a). Seroprevalence of bluetongue in ruminants of Jharkhand. Veterinary World, 8(3), 346-349. https://doi.org/10.14202/ vetworld.2015.346-349

Tigga, P., Joardar, S. N., Banerjee, D., Samanta, I., Isore, D. P., Batabyal, K., \& Dey, S. (2015b). Detection of bluetongue virus vector and its characteristics in Jharkhand. Indian Journal of Animal Health, 54(1), 9-16.

Toussaint, J. F., Sailleau, C., Mast, J., Houdart, P., Czaplicki, G., Demeestere, L., Vandenbussche, F., Van Dessel, W., Goris, N., Breard, E., Bounaadja, L., Thiry, E., Zientara, S., \& De Clercq, K. (2007). Bluetongue in Belgium, 2006. Emerging Infectious Diseases, 13, 614-616.

Uppal, P. K., \& Vasudevan, B. (1980). Occurrence of bluetongue in India. Indian Journal of Comparative Microbiology, Immunology and Infectious Diseases, $1,18-20$.

Vasudevan, B. (1982). A note on bluetongue infection among sheep in India. In M. L. Mehrotra (Ed.), Proceedings of National workshop on bluetongue (pp. 129-144). IVRI, Izatnagar.

Waghmare, S. G. \& Deshmukh, V. V. (2006). Sero-epidemiology of bluetongue disease in Maharashtra state. National seminar on "strategies for control of bluetongue" (p 39.)

Yang, H., Gu, W., Li, Z., Zhang, L., Liao, D., Song, J., Shi, B., Hasimu, J., Li, Z., Yang, Z., Zhong, Qi., \& Li, H. (2021). Novel putative bluetongue virus serotype
29 isolated from inapparently infected goat in Xinjiang of China. Transboundary and Emerging Diseass, 68(4), 2543-2555.

Zientara, S., Sailleau, C., Viarouge, C., Höper, D., Beer, M., Jenckel, M., Hoffmann, B., Romey, A., Bakkali-Kassimi, L., Fablet, A., Vitour, D., \& Bréard, E. (2014). Novel Bluetongue Virus in Goats, Corsica, France, 2014. Emerging Infectious Diseases, 20, 2123-2125.

\section{Publisher's Note}

Springer Nature remains neutral with regard to jurisdictional claims in published maps and institutional affiliations.

\section{Submit your manuscript to a SpringerOpen ${ }^{\circ}$ journal and benefit from:}

- Convenient online submission

- Rigorous peer review

- Open access: articles freely available online

- High visibility within the field

- Retaining the copyright to your article

Submit your next manuscript at $\boldsymbol{\nabla}$ springeropen.com 